\title{
LECTURERS FROM MACEDONIA ELECTED FOR THE FIRST TIME TO THE FACULTY OF MEDICINE IN SKOPJE IN THE PERIOD 1961-63
}

\author{
Doncho Donev ${ }^{1}$, Momir Polenakovic ${ }^{2}$, Nada Pop-Jordanova ${ }^{2}$ \\ ${ }^{1}$ Institute of Social Medicine, Faculty of Medicine, Ss Cyril and Methodius University, Skopje, Republic of Macedonia
${ }^{2}$ Macedonian Academy of Sciences and Arts, Skopje, Republic of Macedonia
}

Corresponding author: Doncho Donev, MD, PhD, Professor, Institute of Social Medicine, Faculty of Medicine, Ss Cyril and Methodius University, 1000 Skopje, R. Macedonia. Phone: +389 70 244760, E-mail: dmdonev@gmail.com

"To get to know, to discover, to publish - this is the destiny of a scientist" - François Arago (1786-1853)

\section{ABSTRACT}

Aim: To present a group of young doctors from R. Macedonia who were elected as lecturers at the Faculty of Medicine (FM) in Skopje, R. Macedonia, in the period 1961-63.

Method: A retrospective study based on archive materials, encyclopaedias and jubilee publications of the FM and Faculty of Dentistry in Skopje, other relevant sources of information, and a review of the relevant literature.

Results: The Skopje FM was founded in 1947 and the first meeting of the Teachers' Council of the Faculty was held on March 17, 1947. The first generation of 153 students was enrolled in the autumn of 1947 and the first lecture was delivered on November 3, 1947.

Besides 15 doctors from R. Macedonia - faculty staff, who had been appointed in the period from 1947-54, and a group of 24 lecturers from R. Macedonia who had been elected assistant professors in the period from 1955-60, an additional group of 17 Macedonian lecturers had been elected for the first time in the period from 1961-63. Those 56 pioneers and coryphaei of medicine in R. Macedonia played important roles in the establishing and/or initial and further development of a number of the faculty departments/ chairs, institutes and clinics within the newly established FM in Skopje in 1947 and in the first 15-20 years of its initial development, until 1960s and later.

Conclusion: The Skopje FM, founded in 1947, played a crucial role in the education of medical professionals, in improving the poor health status of the population and the overall further development of the health system and provision of health care to the population of R. Macedonia. The contribution of the third group of 17 lecturers from R. Macedonia in furthering the development of the Skopje FM, during the 1960s and later, was very important.

Keywords: faculty, medical; establishment, initial development; education, medical; teaching; Republic of Macedonia; doctors from R. Macedonia

\section{INTRODUCTION}

In the years after the Second World War the then People's Republic (PR) of Macedonia was facing very difficult economic, cultural and health situations. Besides a devastated and ruined country, poverty and starvation in an exhausted and predominantly agricultural population, a culture in regres- 
sion and poor economic conditions, the healthcare services in PR Macedonia were under-developed and very weak with only 120 doctors and the same number of nurses for about 1,200,000 inhabitants or 1 doctor and 1 nurse per 10,000 population. The health status of the population was burdened with neglected pathology, numerous endemic spots and high morbidity and mortality, especially of the newborn, infants and small children [1-6]. During the 1950s and early 1960s the situation was slightly improved, but still the health status of the population was very poor with a huge shortage of medical staff. The gigantic battle against poverty and diseases in PR Macedonia in the post-war period continued in 1960s. An essential need was to intensify the education of medical professionals, qualified and educated medical staff that PR Macedonia still badly lacked in the 1960s [1, 2, 6-7].

\section{Aim}

This is the fifth consecutive article in a series published in this journal in order to explore the contribution of the three main groups of doctors and lecturers (coming from Croatia and Serbia, in the first and second articles, and the doctors and lecturers from Macedonia in the third, fourth and this fifth article) to the establishment and initial development of the Faculty of Medicine (FM) in Skopje, PR Macedonia, in the period 1947-63 and later [4-7]. The aim of this study is to present the third group of 17 young doctors from Macedonia who were elected as lecturers in 1961-63 and contributed to further development of the Skopje FM, as well as the Department/Faculty of Dentistry in Skopje, R. Macedonia, in 1960s and later.

\section{METHODS}

Various kinds of documentation, first of all the reports from Bulletins of the University in Skopje on the election of lecturers at the Skopje FM, as the most reliable sources, archive materials, encyclopedias and biographical dictionaries from Macedonia and other countries, statistical records and jubilee publications of the FM and the Faculty of Dentistry in Skopje, the Macedonian Medical Society and other institutions, a review of the relevant literature and other relevant sources of information have been consulted in order to meet the aim and objectives of this study.

\section{RESULTS}

The Skopje FM was established in 1947 [2, $4,8]$. The first meeting of the Teachers' Council of the Skopje FM was held on 17th March, 1947. The General County (Zemska) Hospital in Skopje provided core medical personnel and recruited the first teachers from Macedonia to the newly established FM in Skopje. The departments of the hospital were transformed into the first ten clinics, all together sharing 640 hospital beds [1, 2, 8-11].

The first six institutes of the Skopje FM have been formed in 1947, located in the temporary prefabricated premises of the Secondary Nursing School and the Institute of Hygiene. At the same time construction of the building of the institutes began, into which the institutes moved in late 1948 and early 1949. Two amphitheaters, with 150 seats each, for theoretical lectures were constructed within the building of the institutes [4-12].

The construction of the new clinical block building started in 1953 with great support from Macedonian emigrants in the USA, Canada and Australia. The building of the clinical block was completed and ready for use in 1956. During the 1950s a number of new buildings, clinics and accessory buildings were constructed, so that the Skopje FM grew into a modern medical centre equipped with all the necessary preclinical and clinical facilities [1, 2, 6, 8, 11-13].

The regular education process for the first generation of 153 students enrolled at the Skopje FM began on November 3, 1947, in accordance with the 6-year Plan and study regimen identical to the plans and regimens of study in the other medical faculties in FPR Yugoslavia [1, 2, 4-6, 9-11, 14-16]. At that period of the initial educational process and real existence of the Skopje FM there were 19 teachers and 40 medical doctors, some of them being assistant lecturers [13-16].

The Skopje FM was the basis for the formation of the Faculty of Dentistry and the Faculty of Pharmacy in Skopje, providing continuously and to the present time interdisciplinary support to the teaching process in those faculties $[2,3,8]$.

Lecturers from Macedonia elected for the first time in 1961-63, who contributed to the further development of the Faculty of Medicine in Skopje 
Besides the first group of 15 leading doctors and lecturers from Macedonia who contributed the most to the establishment and/or initial development of the Skopje FM, in the period 1947-54 and a group of 24 young lecturers (assistant professors) from Macedonia who were elected in the period from 1955-60, an additional group of 17 young lecturers (assistant professors) from Macedonia were elected in the period 196163. They strengthened the staffing of the existing 7 clinics and 8 institutes and were a power mov- ing forward for the further development of the healthcare, professional, research and educational activities of the Skopje FM in the 1960s and later. Some essential details about this young group of lecturers are presented in Table 1 by years of election, in alphabetical order of the first letter of family name of the lecturer.

This group of 17 young teachers from PR Macedonia, shown in Table 1, contributed to the further development of certain departments/

Table 1. Lecturers from Macedonia who were for the first time elected assistant professors at the Faculty of Medicine in Skopje in the period from 1961-63 [17-37]

\begin{tabular}{|l|l|l|l|l|c|}
\hline Family and first name & $\begin{array}{l}\text { Place and year } \\
\text { of birth }\end{array}$ & $\begin{array}{l}\text { Place and year } \\
\text { of graduation }\end{array}$ & $\begin{array}{l}\text { Elected } \\
\text { assistant } \\
\text { professor }\end{array}$ & $\begin{array}{l}\text { Elected } \\
\text { (re-elected) as- } \\
\text { soc. professor }\end{array}$ & $\begin{array}{l}\text { Elected } \\
\text { professor }\end{array}$ \\
\hline Kepeski Dimko & Prilep, 1918 & Belgrade, 1948 & 1961 & $1967(+1972)$ & 1977 \\
Kovačev Vančo & Radoviš, 1927 & Skopje, 1954 & 1961 & $1966(+1970)$ & 1974 \\
Levi Salvator & Bitola, 1919 & Belgrade, 1947 & 1961 & - & - \\
Nikodijević Branislav & Skopje, 1929 & Zagreb, 1954 & 1961 & $1967(+1973)$ & 1977 \\
Ruben Remon & Skopje, 2011 & Graz, 1934 & 1961 & $1967(+1972)$ & 1977 \\
Tavčiovski Ivan & Prilep, 1923 & Belgrade, 1953 & 1961 & $1967(+1973)$ & 1977 \\
\hline Anastasov Mitruš & Probištip, 1918 & Belgrade, 1947 & 1962 & - & - \\
Kotevski Ljubomir & Skopje, 1923 & Belgrade, 1951 & 1962 & $1967(+1972)$ & 1977 \\
Minčev Kiril & Kavadarci, 1922 & Belgrade, 1950 & 1962 & $1967(+1973)$ & 1977 \\
Serafimov Kočo & Tetovo, 1922 & Belgrade, 1949 & 1962 & $1967(+1973)$ & 1977 \\
Tofović Petar & Tetovo, 1920 & Belgrade, 1948 & 1962 & $1967(+1973)$ & 1977 \\
\hline Babamova Aleksandra & Strumica, 1921 & Zagreb 1948 & 1963 & $1970(+1976)$ & 1979 \\
Grozdev Ljupčo & Štip, 1930 & Skopje, 1955 & 1963 & $1968(+1978)$ & 1980 \\
Karanfilski Borislav & Kumanovo, 1928 & Skopje, 1955 & 1963 & $1968(+1974)$ & 1977 \\
Petruševska Marika & Ohrid, 1925 & Belgrade, 1949 & 1963 & $1968(+1976)$ & 1978 \\
Taškova Divna & Kumanovo, 1921 & Belgrade, 1948 & 1963 & $1970(+1976)$ & 1979 \\
Čumbelić Nada & Veles, 1921 & Zagreb, 1947 & 1963 & $1968(+1974)$ & 1979 \\
\hline
\end{tabular}

chairs and organizational units (clinics and institutes) of the Skopje FM in the 1960s and later, and thus some of them performed certain managerial functions. Below are shown 7 clinics (orthopedics, dermatovenreology, dentistry, urology, internal medicine, abdominal surgery and neurosurgery), 8 institutes (physiology, radiology, pharmacology, chest diseases and tuberculosis, biochemistry, pathological anatomy, pathological physiology and histology and embryology), and the relevant chairs within them. This third group of 17 young doctors and teachers from R. Macedonia are presented with brief CVs and photos in boxes, in alphabetical order according to the first letter of the surname and grouped by the organizational unit (clinic or institute) in which they were employed and contributed to its further development.

\section{Development of the Clinic of Orthopaedics}

The Clinic of Orthopaedic Diseases, as a separate organizational unit within the Skopje FM was founded in November 1956 because of the strong need for special treatment of the orthopaedic diseases in Macedonia and to provide training in orthopaedics and the organization of scientific research work in the domain of fundamental and applicative problems of the bones and joints system and treatment of the orthopaedics diseases, congenital anomalies and deformities.

Earlier activity began with only orthopaedic polyclinical work by a doctor, nurse and auxiliary personnel in makeshift premises. In 1958, the Orthopaedic Diseases Clinic received space in the building of the Surgical Clinic, with a capacity of 60 beds and two rooms in the same 
building for polyclinical work $[8,11,12]$. Professor Dr. Djuro Sušec was the first lecturer and director who made a substantial contribution to the further development of the Orthopaedic Diseases Clinic within the Skopje FM. In the first few years his professional team included one surgeon who completed specialization in orthopaedics in 1959, Dr. Dimko Kepeski (Box 1), and two doctors on specialization in orthopaedics, Dr. Lj. Serafimov and Dr. S. Ralev.

\begin{tabular}{|l|l|}
\hline Box 1. Dimko Kepeski, Professor in Orthopaedics [12, 17, 21, 38, 39] \\
\hline $\begin{array}{l}\text { Dr. Dimko Kepeski was born in Prilep on } \\
\text { 14.09.1918. He graduated at the FM in Belgrade in 1948 } \\
\text { and completed specialization in surgery in 1954 and in } \\
\text { orthopaedics in 1959 at the Skopje FM. After habilitation } \\
\text { he was elected Assist. Professor in 1961, Assoc. Profes- } \\
\text { sor in 1967 (re-elected in 1972) and Professor in 1978. } \\
\text { Prof. Kepeski realized professional stay with advanced } \\
\text { education in Ljubljana and Zagreb, as well as in several } \\
\text { orthopaedics centres in England, Italy, Austria and Tur- } \\
\text { key. He is a founder of the modern orthopaedics and the } \\
\text { orthopaedics school in R. Macedonia. He contributed to } \\
\text { the advancement of the treatment of osteomyelitis, TBC } \\
\text { of the skeletal system and scoliosis. } \\
\text { Prof. D. Kepeski was Director of the Orthopaedics } \\
\text { Clinic from 1969-74. He has published more than 100 } \\
\text { professional and scientific papers. } \\
\text { Prof. Dr. Dimko Kepeski died in Skopje on } \\
18.04 .1997 \text { at the age of } 78 \text { years. }\end{array}$ \\
\hline
\end{tabular}

\begin{tabular}{|c|c|}
\hline x 2. Vančo Kovačev, Professor of $P$ hy & $22,40]$ \\
\hline & $\begin{array}{l}\text { Dr. Vančo Kovačev was born in Radoviš on } \\
\text { 26.05.1927. He started medical studies in Leningrad } \\
\text { (Saint Petersburg) in } 1947 \text { for two years and continued } \\
\text { and graduated at the Skopje FM in 1954. Being employed } \\
\text { at the Institute of physiology he realized professional vis- } \\
\text { its and stays in Nancy and Paris, Geneva and Belgrade, } \\
\text { and then he completed his habilitation at the Skopje FM } \\
\text { in 1960. Next year he has been elected Assist. Professor, } \\
\text { in } 1966 \text { as Assoc. Professor and re-elected in 1970, and in } \\
1974 \text { as Professor. From 1963-65 he upgraded his knowl- } \\
\text { edge in physiology at NIH, Bethesda, USA. His ambition } \\
\text { and devotion to the scientific research of hormones and } \\
\text { metabolism resulted in successful presentation of doctor- } \\
\text { al dissertation in 1981. } \\
\text { Prof. V. Kovačev was Director of the Institute of } \\
\text { Physiology from 1973-88, till his retirement at the age } \\
\text { of } 60 \text { years. } \\
\text { During his professional career Prof. V. Kovačev } \\
\text { performed a number of additional important leadership } \\
\text { functions and duties i.e. Vice Dean at the FM-Skopje } \\
\text { (1969-71 and 1976-78), Acting Director of the Joint In- } \\
\text { stitutes (1976-77), President of the Association of societ- } \\
\text { ies of physiology in Yugoslavia (1985-7) etc. } \\
\text { Prof. Dr. Vančo Kovačev died in Skopje on } \\
\text { 24.12.2007 at the age of } 80 \text { years. }\end{array}$ \\
\hline
\end{tabular}




\section{Development of the Institute and Chair of Physiology}

The Institute of Physiology was founded in 1947 and the first director was Prof. Dr. Miloe Vidakovic, providing theoretical lectures both for Physiology and Pathological Physiology [5]. Two years later, in 1949, the Institute of Pathologic Physiology was created in the same premises. In 1952, the Institute of Pathological Physiology was established as the newly independent Institute. Assistant Professor Ishac Tadjer was appointed the first Director of and Head of the Chair of Pathologic Physiology $[6,12,14]$. Prof. Miloe Vidaković served as Director of the Institute of Physiology till his retirement in 1957. From the end of 1957 till September 1961 the teaching process of Physiology at the Skopje FM was coordinated and realized by Prof. Dr. Milutin Neškovic from the Belgrade FM. Then, these functions have been carrying by Prof. Aleksandra Volkanoska until her retirement in 1972. In April 1961, Dr. Vanco Kovachev was elected as Assist. Professor and, in 1972 he was appointed director of the Institute and head of the Department of Physiology (Box 2).

\section{Development of the Institute of Radiology}

The Institute of Radiology was established in parallel with the Skopje FM, in 1947, by transforming the previous Department of Roentgenology of the General County Hospital in Skopje. At first the Institute was located in a shed, auxiliary premises of the Surgery Clinic. In 1957, the Institute was moved to a new building and was supplied with new equipment. In 1963, the Institute of Radiology was divided into two departments - for radio-diagnostics and for radiotherapy. Later, in 1979, these departments were transformed into two institutes: the Institute of Radiology and the Institute of Radiotherapy and Oncology, located in separate new buildings with modern equipment $[9,11,12]$. The first Head of the Institute of Radiology, from 1947 to 1955, was Prim. Dr. Ivan Anastasov [6], who was the first honorary lecturer for the course in radiology, 1951-57.

\begin{tabular}{|l|l|}
\hline Box 3. Salvator Levi, Assistant Professor in Radiology [12, 17, 23] \\
\hline & $\begin{array}{l}\text { Dr. Salvator Levi was born in Bitola on 28.05.1919. } \\
\text { He started medical studies in Belgrade in 1938 and in } \\
1941 \text { moved to Sofia. From 1942-44 he was imprisoned } \\
\text { in Pleven and in Oct. 1944 he joined the People's Lib- } \\
\text { eration Army in Macedonia. In 1945 he continued to } \\
\text { study in Belgrade and graduated in 1947. After a year of } \\
\text { service as a doctor in the Ministry of Interior he started } \\
\text { specialization in radiology in 1949 in Skopje and in 1951 } \\
\text { was appointed as Head of the Department of Radiology } \\
\text { in Bitola. } \\
\text { In 1953 he completed specialization in radiolo- } \\
\text { gy in Zagreb and realized almost two year professional } \\
\text { stay in Paris. He joined the Institute of Radiology at the } \\
\text { Skopje FM in 1955 when he was elected and in 1960 } \\
\text { re-elected as assistant lecturer. He introduced a number } \\
\text { of new diagnostic methods and techniques for gastro-in- } \\
\text { testinal disorder diagnostics and in 1961 was elected as } \\
\text { Assist. Professor in Radiology. } \\
\text { Assist. Prof. Dr. S. Levi established and equipped } \\
\text { Departments of Radiology in Bitola and Prilep. } \\
\text { Assist. Prof. Dr. Salvator Levi died in Skopje during } \\
\text { the earthquake on 26.07.1963 at the age of 44 years. }\end{array}$ \\
\hline
\end{tabular}

In 1955 Dr. Josip Novak was elected as assistant professor and the first two assistant lecturers in the subject of radiology at the MF-Skopje were elected: Dr. Dimitar Tevchev and Dr. Salvator Levi [4, 7]. In 1957 Dr. D. Tevchev, and in
1961 Dr. Salvator Levi (Box 3) were elected as assistant professors. The Chair of Radiology was established in 1958, and the first Head of the Chair, as well as director of the Institute, was appointed Assist. Professor Dimitar Tevchev. 


\section{Development of the Institute and Chair of Pharmacology}

At first, after its establishment in 1947, the Institute of Pharmacology was located in a shed in the grounds of the Faculty. When the building of the institutes at the Skopje FM was completed in 1948, the Institute of Pharmacology was moved into new premises $[8,11,12]$. The pharmacology course started in the academic year 1950-51 and was taught by the founder and the first Director of the Institute of Pharmacology, Assist. Professor Dr. Dimitrie Atanacković untill 1957, when he left Skopje and moved to Belgrade FM [5, 12]. Next year a young Assist. Lecturer Branislav Nikodijević (Box 4) was moved from the Institute of Physiology to the Institute of Pharmacology [12].

\begin{tabular}{|l|l|}
\hline Box 4. Branislav Nikodijević, Professor of Pharmacology [12, 19, 24, 41-43] \\
\hline & $\begin{array}{l}\text { Dr. Branislav Nikodijević was born in Skopje } \\
\text { on 12.02.1929. He started medical studies in Prague in } \\
\text { 1947. Next year he had to leave Chehoslovakia and con- } \\
\text { tinued his studies in Zagreb where he graduated in 1954. } \\
\text { He started his career as Assist. Lecturer in physiology } \\
\text { at the Zagreb FM till 1956 when he moved to the same } \\
\text { institute at the Skopje FM. In 1958 he was appointed As- } \\
\text { sist. lecturer in pharmacology. He realized several a few- } \\
\text { month stays in Belgrade, Zagreb, Ljubljana and Sarajevo. } \\
\text { He realized three one-year professional stays at NIH in } \\
\text { Bethesda, USA (in 1961, 1967 and 1974) and introduced } \\
\text { a number of new experimental methods in pharmacology } \\
\text { at the Skopje FM and a new specialty for doctors - Clin- } \\
\text { ical Pharmacology. } \\
\text { Prof. B. Nikodijević presented habilitation in 1961 } \\
\text { and has been elected Assist. Professor of Pharmacol- } \\
\text { ogy and Toxicology, then in 1967 elected and in 1973 } \\
\text { re-elected as Assoc. Profesor, and in 1977 as Professor of } \\
\text { Pharmacology and Toxicology at the Skopje FM. } \\
\text { Prof. B. Nikodijević, was appointed Director of } \\
\text { the Institute of Pharmacology and Toxicology at the Sko- } \\
\text { pje FM in 1963 serving such managerial function for 27 } \\
\text { years, up to 1989. He was elected twice Vice Dean (1965- } \\
69) \text { and twice Dean of the Skopje FM (1984-88). He was } \\
\text { founder and the first Dean of the Faculty of Pharmacy in } \\
\text { Skopje, established in 1977. } \\
\text { Prof. Dr. Branislav Nikodijević died in Skopje on } \\
21.12 .2009 \text { at the age of 80 years. }\end{array}$ \\
\hline
\end{tabular}

\section{Development of the Clinic and Chair of Dermatovenereology}

The Skin and Venereal Diseases Clinic at the Skopje FM was established in 1947 by transforming the previous Department of Skin and Venereal Diseases of the General County Hospital, with about 70 hospital beds shared in male and female departments, in limited and inappropriate conditions in the basement of the surgery clinic building. In 1956, the Skin and Venereal Diseases Clinic moved to the ground floor of the clinical block building and gained additional space within the first building for polyclinics at the Skopje FM [11, 12]. The first director of the Clinic, in the period of the foundation of the Clinic and in the next three years, from 1947 to 1950 , was Prof. Dr. Ernest Hammerschmidt, who came from the Ljubljana FM, to help and support the newly established Skopje FM. In 1950, Assist. Professor Dr. Done Miovski was appointed Director of the Clinic and, a few months later, the Head of the Chair of Skin and Venereal Diseases [6. 12]. In 1951, Dr Remon Ruben (Box 5) as a doctor specialist in Skin and Venereal Diseases was employed at the Clinic being later on elected lecturer and professor. 


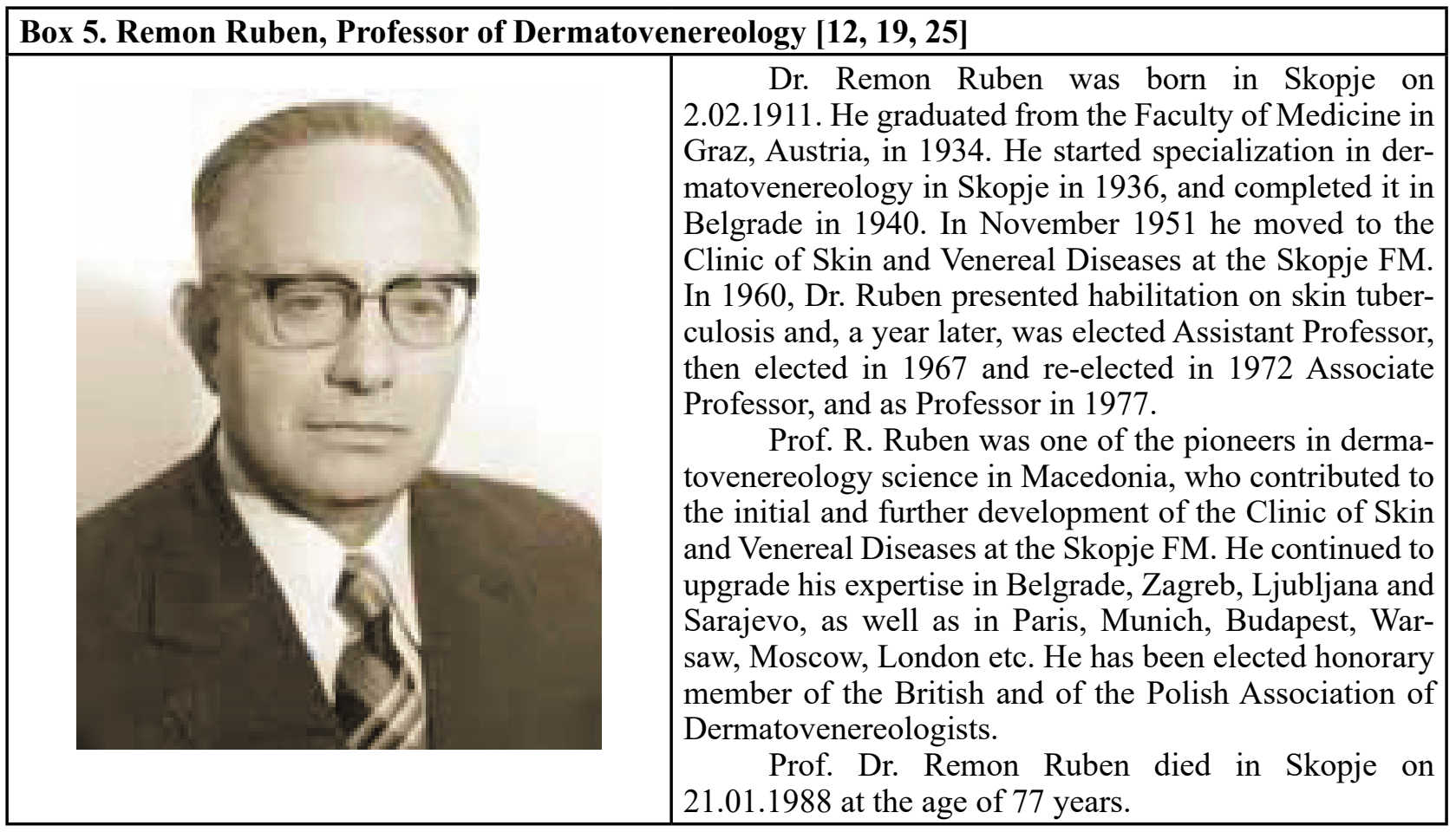

6. Development of the Clinic and Chair, and Faculty of Dentistry

The Skopje FM was the basis for the formation of the Department of Dentistry, in 1959, and then the Faculty of Dentistry in Skopje in 1977 , as well as the Faculty of Pharmacy in Skopje in $1977[8,11,12]$.

The Mouth, Dental and Jaw Diseases Clinic had been established in 1948 within the Skopje FM, and in 1951 an in-patient department within the Clinic was created with 12 hospital beds. The first Head of the Clinic was Dr. Dimitar Smilev, who was elected Assistant Professor and delivered the first lectures on the dentistry course in 1952 [6]. A number of young dentists were employed and sent for further education and specialization to the educational centers for dentistry in Belgrade, Zagreb and Ljubljana. Prof. Smilev, with support from Prof. Dr. Joža Rant from the Faculty of Dentistry in Ljubljana and Prof. Dr. Laza Petrović from the Faculty of Dentistry in Belgrade, led the process for the preparation of a proposal for establishing the Department of Dentistry within the FM-Skopje. In 1959, the Mouth, Dental and Jaw Diseases Clinic was transformed into the Department of Dentistry within the Skopje FM, which grew into the independent Faculty of Dentistry in Skopje in $1977 / 78[2,3,11,12]$.

The first generation of 38 students at the Department of Dentistry was enrolled in 1959. Beside the Head of the Department, Prof. Dr. Dimitar Smilev, the faculty staff was consisted of two other lecturers, Assoc. Prof. Dimitar Železarov [7] and Assist. Prof. Ivan Tavčiovski (Box 6), and two assistant lecturers, Gjorgi Simov and Nevenka Tomčeva. The teaching process at the Department of Dentistry in Skopje was supported by some lecturers from the Faculty of Dentistry in Belgrade (Professors Ivan Bikar, Milisav Teodosijević, Dragoljub Dzaić and Milutin Kremžar) until more lecturers from Macedonia had been educated and elected $[8,12,20]$. 


\begin{tabular}{|l|l|}
\hline Box 6. Ivan Tavčiovski, Professor of Dentistry [12, 19, 20, 26] \\
\hline $\begin{array}{l}\text { Dr. Ivan Tavčiovski was born in Prilep on } \\
\text { 25.11.1923. He graduated from the Faculty of Dentistry } \\
\text { in Belgrade in 1953. He started to work at the Department } \\
\text { of Dentistry within Skopje FM in 1955 and presented his } \\
\text { habilitation in 1961 when he was elected Assistant Pro- } \\
\text { fessor for the course of Dental Pathology and Therapy at } \\
\text { the Skopje FM. Later on, in 1972, he also became spe- } \\
\text { cialist in mouth and teeth diseases. He was elected (1967) } \\
\text { and re-elected Associate Professor (1973), and Professor } \\
\text { in 1977. In the meantime he continued to upgrade his } \\
\text { expertise in Belgrade, Zagreb and Ljubljana, as well as } \\
\text { in Paris and Warsaw. } \\
\text { Prof. I. Tavčiovski was the founder and the first } \\
\text { Head of the Clinic of Dental Pathology and Therapy be- } \\
\text { ing responsible lecturer for the same subject, as well as } \\
\text { for the subject Child and Preventive Stomatology. } \\
\text { Prof. I. Tavčiovski was performing various profes- } \\
\text { sional-social activities through the Socialist Alliance and } \\
\text { Trade Unions, Macedonian Medical Society and the As- } \\
\text { sociation of Dentists of Yugoslavia. He served Vice Dean } \\
\text { at the Skopje FM from 1971-73, Director of the Dentistry } \\
\text { Clinics and Dean of the Faculty of Dentistry in Skopje } \\
\text { with four mandates. } \\
\text { Prof. Dr. Ivan Tavčiovski died in Skopje on } \\
\text { 12.05.2001 at the age of 78 years. }\end{array}$ \\
\hline
\end{tabular}

\section{Development of the Clinic and Chair of} Surgery

The Surgical Clinic at the Skopje FM was established in 1947 with 160 hospital beds, and after three years (1950) the number of beds had increased to 180 . In the next nine years, until 1959, the number of beds again increased to 275 $[9,11,12,14]$.

The first two directors of the Surgical Clinic were Prof. Dr. Dimitrie Juzbašić (1947-53) and Prof. Dr. Branko Oberhofer (1954-56), both from the Zagreb FM [4, 12]. During the period from 1955 to 1956, when Prof. Oberhofer was absent from time to time and after he left Macedonia in 1956, Assist. Prof. Panče Karagjozov was appointed as Acting Director of the Clinic of Surgery and Chief of the Chair until 1958 when Prof. Dr. Bogosav Dragojević from the Belgrade FM joined the Surgery Clinic as director and head of the chair $[6,8,12]$.

Early in the first years of its existence the clinic had the character of a general medical sur- gical facility, and later on, in 1954, was transformed into many super-specialist departments and sections that grew into today's specialized university clinics (Urology, Abdominal Surgery, Traumatology, Thoracic and Vascular Surgery, and Paediatric Surgery), [11, 12].

The Urology Clinic was established and headed from 1954 to 1961 by Assoc. Prof. Dr. Sotir Stavridis $[6,12]$ and, after his sudden death, in 1961, Assist. Prof. Dr. Mitruš Anastasov (Box 7) was appointed Head of the Clinic.

The Abdominal Surgery Department, with male and female sections, was headed by the young doctors, later on professors, Krsto Georgiev [7] and Kočo Serafimov (Box 8).

In October 1958 two additional independent clinics were established. The first one was the Neurosurgery Clinic, headed by then Assist. Lecturer Dr. Petar Tofović (Box 9), while the second was the Plastic and Reconstructive Surgery Clinic, headed by Assist. Prof. Jovan Panovski $[7,12]$. 


\begin{tabular}{|l|l|}
\hline Box 7. Mitruš Anastasov, Assistant Professor of Surgery [12, 27, 44] \\
\hline & $\begin{array}{l}\text { Dr. Mitruš Anastasov was born in Probištip on } \\
17.06 .1918 \text {. He started his medical studies in Belgrade } \\
\text { in 1939, for the first two years, and continued in Sofia, } \\
\text { with some interruptions, for the next three years. After } \\
\text { the World War II was over, he continued medical studies } \\
\text { at the Belgrade FM and graduated in 1947. Then he com- } \\
\text { pleted specialization in surgery at the Skopje FM in 1952 } \\
\text { and the next year was appointed Head of the Department } \\
\text { of Surgery and Director of the General Hospital in Štip, } \\
\text { serving at those positions for the next eight years. } \\
\text { Dr. Mitrus Anastasov realized three-month stay in } \\
\text { Hammersmith Hospital in London in 1957. He moved } \\
\text { to Skopje and was appointed Head of the Department of } \\
\text { Urology at the Skopje FM in 1961. In early 1962 he was } \\
\text { elected Assistant Professor of Surgery at the Skopje FM. } \\
\text { Assist. Prof. M. Anastasov realized his second visit } \\
\text { to London in 1965 with seven-month stay at the Depart- } \\
\text { ment of Urology of Hammersmith Hospital in London. } \\
\text { Assist. Prof. Mitruš Anastasov died on duty at the } \\
\text { Clinic of Urology at the Skopje FM on 26.09.1965 at the } \\
\text { age of 47 years. }\end{array}$ \\
\hline
\end{tabular}

\begin{tabular}{|l|l|}
\hline Box 8. Kočo Serafimov, Professor of Surgery [12, 19, 30, 44, 45] \\
\hline \multicolumn{1}{|c|}{$\begin{array}{l}\text { Dr. Kočo Serafimov was born in Tetovo on } \\
9.05 .1922 . \text { He started medical studies at the FM-Bel- } \\
\text { grade in } 1940 \text { for the first two semesters and then moved } \\
\text { to Sofia in } 1942 \text { to continue with studies for the next two } \\
\text { years. In the post-war period he continued medical studies } \\
\text { at the Belgrade FM and graduated in 1949. He complet- } \\
\text { ed specialization in surgery in 1955 and a year later was } \\
\text { appointed Chief of the Department for female abdominal } \\
\text { surgery within the Surgery Clinic at the FM-Skopje. In } \\
1959 \text { he presented habilitation on cholelithiasis and in } \\
1962 \text { was elected Assist. Professor in surgery. Then, he } \\
\text { was elected in 1967 and re-elected Assoc. Professor in } \\
1973 . \text { He presented doctoral dissertation in 1976 at the } \\
\text { Belgrade FM and was elected Professor in surgery at the } \\
\text { Skopje FM in 1977. } \\
\text { Prof. K. Serafimov continued to upgrade his ex- } \\
\text { pertise in many other clinics in Yugoslavia and a number } \\
\text { of centers of surgery in the European countries (Paris, } \\
\text { Lion, London, Munich). } \\
\text { Prof. K. Serafimov was appointed Head of the De- } \\
\text { partment of Abdominal Surgery and served such mana- } \\
\text { gerial position in the period from 1976-87. He introduced } \\
\text { camera recording with direct TV presentation of certain } \\
\text { surgical interventions for students in the Amphitheatre. } \\
\text { Prof. Dr. Kočo Serafimov now lives in Skopje at } \\
\text { the age of 96 years. }\end{array}$} \\
\hline
\end{tabular}




\begin{tabular}{|l|l|}
\hline Box 9. Petar Tofović, Professor of Surgery [12, 19, 31, 44] \\
\hline \multicolumn{1}{|c|}{ Dr. Petar Tofović was born in Tetovo on 3.02.1920. } \\
He started medical studies at the Belgrade FM in 1938 \\
and, during the war-time from 1941-45 he was volun- \\
teer, at first, and day-laborer at the Dept. of Orthopaedics \\
within the General State Hospital in Belgrade till 1944 \\
when he joined Yugoslav Liberation Army. In 1946 he \\
continued medical studies in Zagreb and graduated in \\
1949. Then he completed his specialization in surgery in \\
Skopje (1955), and was appointed at first Chief of the \\
Dept. of Traumatology (1957) and then Chief of the new- \\
ly created Dept. of Neurosurgery (1958). He continued \\
to upgrade his expertise through professional visits and \\
stays in many clinics in Yugoslavia (Belgrade, Zagreb) \\
and a number of centers of neurosurgery in the Europe- \\
an countries (Lion, Paris, Goteborg, Hamburg and So- \\
fia), as well as contributed to congresses of traumatology \\
and neurosurgery in Yugoslavia and various European \\
countries. He was elected Assist. Professor in 1962, then \\
elected in 1967 and re-elected Assoc. Professor in 1973, \\
and Professor in 1977. \\
Prof. P. Tofović is the founder of contemporary \\
neurosurgery in Macedonia, an exceptional erudite and \\
pedagogue, scientist and public expert with a number of \\
professional-social functions he performed. \\
Prof. Dr. Petar Tofović died in Skopje on \\
21.07 .1990 at the age of 70 years.
\end{tabular}

\section{Development of the Internal Medicine Clinic and Chair}

The Internal Medicine Clinic, with about 110 hospital beds, was one of the first nine clinics established at the Skopje FM in March 1947. The first lecturer and Director of the Clinic of Internal Medicine was Prof. Dr. Aleksandar Ignjatovski [5, 12], who came from Belgrade in 1948. Prof. Ignjatovski led the Clinic of Internal Medicine in Skopje until his retirement in 1952. Then Assist. Prof. Dr. Dimitar Arsov was appointed Director of the Clinic and Head of the Chair of Internal Medicine, and served in those positions in the period 1952-74 $[6,12]$.

In the first few years of its existence the Internal Medicine Clinic had the character of a general internal medicine facility and was trans- formed, in 1953 into many super-specialist units and sections that grew, later on in 1975, into today's super-specialist university clinics (Cardiology, Pulmology and Allergology, Gastroenterohepatology, Nephrology, Endocrinology, Rheumatology, Haematology and Toxicology, as well as Clinical Laboratory for biochemical analyses, haematology and cytology, and Internal Medicine Polyclinics), [8, 9, 46].

The first directors/heads of those clinics were young doctors from Macedonia, elected as assistant professors at the Skopje FM in the period from 1955-62: Penčo Davčev (Gastroenterology), Dimitar Hrisoho (Nephrology), Jonče Nedelkovski (Haematology), Radovan Perčinkovski (Cardiology), [7] and Ljubomir Kotevski (Pulmology and Allergology), (Box 10). 


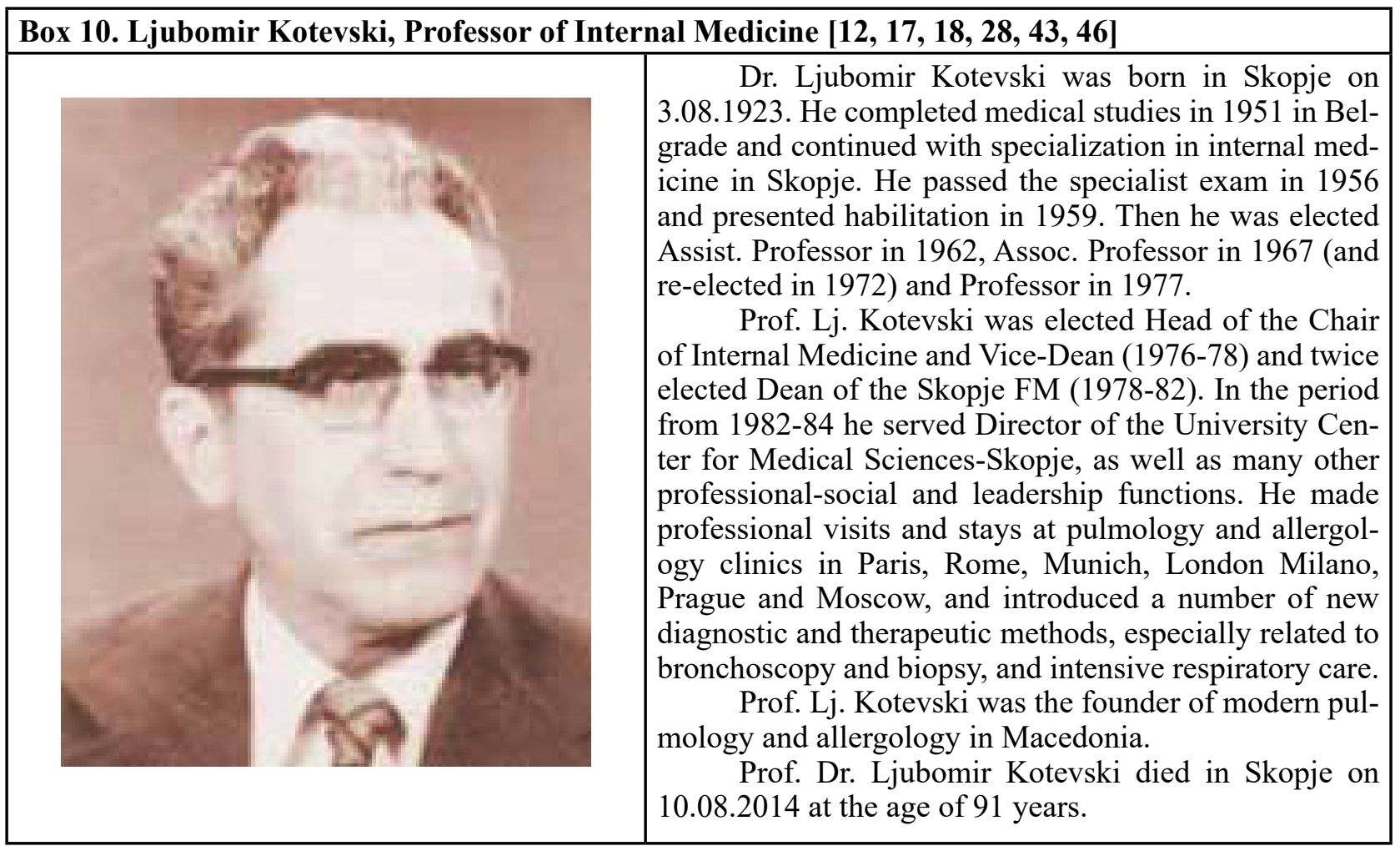

9. Development of the Clinic/ Institute of Chest Diseases and TBC

The Chest Diseases and Tuberculosis Clinic at the Skopje FM was established in 1947 by transforming the previous Department of Chest Diseases and Tuberculosis of the General County Hospital, with about 60 hospital beds within a building adapted from the dormitory of the Nursing/Pharmacy School. A few years later the capacities were slightly improved with some additional new buildings for epidemiology and preventive activities, administration, and an outpatient department. In 1956 the Clinic was transformed into the Tuberculosis Institute of Macedonia and in 1978, in accordance with the decreasing trend in tuberculosis and upward trend in chronic chest diseases, the name of the institution was broadened into the Chest Diseases and Tuberculosis Institute $[1,11,12]$.

The founder and the first director of the Clinic/ Institute of Chest Diseases and Tuberculosis in Macedonia, in the period from 1947 to 1961, was Prof. Dr. Gligor Muratovski [6], and then a young doctor, later on professor, Kiril Minčev (Box 11), was appointed Director of the Clinic/Institute. 


\begin{tabular}{|l|l|}
\hline Box 11. Kiril Minčev, Professor of Phtysiology [12, 19, 29, 44, 47] \\
\hline & $\begin{array}{l}\text { Dr. Kiril Minčev was born in Vataša, Kavadarci, on } \\
\text { 22.07.1922. He started medical studies in Sofia in 1941 } \\
\text { for the first three years and graduated from the Belgrade } \\
\text { FM in 1950. After returning to Skopje he joined the then } \\
\text { Clinic for Chest Diseases at the Skopje FM and completed } \\
\text { specialization in Phtysiology in 1954. During 1955-56 Dr. } \\
\text { K. Minčev upgraded his knowledge in various TBC cen- } \\
\text { ters in Switzerland, France, Germany and Russia, as well } \\
\text { as attending many educational events and congresses of } \\
\text { phtysiology and chest diseases in different European coun- } \\
\text { tries. He presented habilitation in 1961 and contributed for } \\
\text { introducing obligatory BCG immunization. He was elect- } \\
\text { ed Assist. Professor in 1962, then Assoc. Professor in 1967 } \\
\text { (re-elected in 1973) and Professor in 1977. } \\
\text { Prof. K. Minčev was appointed Director of the In- } \\
\text { stitute of Chest Diseases and Tuberculosis in 1962 and } \\
\text { served that position till his retirement in 1987. In addi- } \\
\text { tion, he served Vice-Dean at the Skopje FM (1971-73) } \\
\text { and performed various professional-social and leadership } \\
\text { functions within the Trade Unions, Macedonian Medical } \\
\text { Society, Association of the Medical Societies of Yugosla- } \\
\text { via and related international associations. } \\
\text { Prof. Dr. Kiril Minčev died in Skopje on 28.12.2010 } \\
\text { at the age of 88 years. }\end{array}$ \\
\hline
\end{tabular}

\begin{tabular}{|l|l|}
\hline Box 12. Aleksandra Babamova, Professor of Biochemistry [8, 12, 32, 48] \\
\hline & $\begin{array}{l}\text { Aleksandra Babamova-Vilarova was born in Stru- } \\
\text { mica on 11.06.1921. She enrolled at the Faculty of Phar- } \\
\text { macy in Sofia in 1941 and was studying for the first two } \\
\text { years. She continued in } 1945 \text { and graduated in } 1948 \text { at the } \\
\text { Faculty of Pharmacy in Zagreb. She was elected Assist. } \\
\text { Lecturer in the subjects of chemistry and biochemistry at } \\
\text { the Skopje FM in 1949, University Lecturer in } 1962 \text { and } \\
\text { Assist. Professor in 1963. In the same year she present- } \\
\text { ed habilitation. Then she was elected Assoc. Professor in } \\
1970 \text { (re-elected in 1976) and Professor in 1979. } \\
\text { Prof. A. Babamova realized several few-month } \\
\text { professional visits and stays in Zagreb in 1950s, and } \\
\text { three-month stays in Leuven, Belgium, and Lille, France, } \\
\text { in 1964. She introduced several new methods on bio- } \\
\text { chemical analysis of proteins and lipoproteins and was } \\
\text { author of several manuals for practical exercises in bio- } \\
\text { chemistry and of the first textbook on biochemistry in } \\
\text { Macedonian language, published in 1979. She retired } \\
\text { from the Institute of Biochemistry in 1981. } \\
\text { Prof. Aleksandra Babamova died in Skopje on } \\
\text { 9.06.1995 at the age of 74 years. }\end{array}$ \\
\hline
\end{tabular}


10. Development of the Institute and Chair of Biochemistry

At first, after its establishment in 1947, the Institute of Chemistry and Biochemistry, was located in a shed in the grounds of the Faculty. When the building of the institutes at the Faculty of Medicine was completed in 1948, the Institute of Chemistry and Biochemistry was moved into new premises $[8,11,12]$. The Institute of Biochemistry was integrated and functioned within the Institute of Chemistry, and the biochemistry course was taught by the Professor of Chemistry, Professor Dr. Božidar Belija from 1947-54 [4]. Two separate institutes, Institute of Chemistry and Institute of Biochemistry were created in
1954. The Institute of Biochemistry received its facilities as an independent Institute within the Institutes building of the FM-Skopje [11, 12, 48]. At the same time the Chair/ Department of Biochemistry was established. The Professor Dr. Ivan Berkeš was appointed Director of the Institute and Head of the Department of Biochemistry and he taught the course of biochemistry till 1960 when he moved to Belgrade Faculty of Pharmacy [4]. In early 1960s the Institute of Biochemistry was lead by Prof. Ishac Tadjer, until 1963 when three Assist. Professors of Biochemistry were elected at the Skopje FM - Aleksandra Babamova, Divna Taškova and Nada Čumbelić (Box 12, 13 and 14).

\begin{tabular}{|c|l|}
\hline Box 13. Divna Taškova, Professor of Biochemistry [8, 12, 36, 48] \\
\hline $\begin{array}{l}\text { Divna Taškova-Konstantinova was born in Ku- } \\
\text { manovo on 18.03.1921. She enrolled to the Faculty of } \\
\text { Pharmacy in Belgrade in 1939 and, in Spring 1941 re- } \\
\text { turned to Kumanovo. She continued her studies in 1946 } \\
\text { and graduated in Belgrade in 1948. In the same year she } \\
\text { was elected as the first Assist. Lecturer at the Institute } \\
\text { of Chemistry and Biochemistry at the Skopje FM. Lat- } \\
\text { er on she was elected University Lecturer (1961), Assist. } \\
\text { Professor (1963), Assoc. Professor (1970 and re-elected } \\
\text { in 1976) and Professor (1979). She realized additional } \\
\text { education in Zagreb and Nancy-France in 1950s and pre- } \\
\text { sented habilitation in the field of biochemistry at the Sko- } \\
\text { pje FM in 1963. Her scientific work was directed toward } \\
\text { introducing new methods for biochemical analysis of } \\
\text { cholesterol in milk and lipoproteins in serum with paper } \\
\text { electrophoresis. } \\
\text { Prof. D. Taškova was appointed Acting Director } \\
\text { from 1962-67 and Director of the Institute of Biochemis- } \\
\text { try from 1967 till her retirement in 1981. She also served } \\
\text { Head of the Department/Chair of Biochemistry at the } \\
\text { Skopje FM from 1962-81. In addition, she was engaged } \\
\text { in various professional-social activities within the Skopje } \\
\text { FM, Trade Unions of the health workers of the city of } \\
\text { Skopje, member of the Commission of Biochemistry of } \\
\text { Yugoslavia etc. } \\
\text { Prof. Divna Taškova-Konstantinova died in Sko- }\end{array}$ \\
pje on 16.08.2003 at the age of 82 years.
\end{tabular}




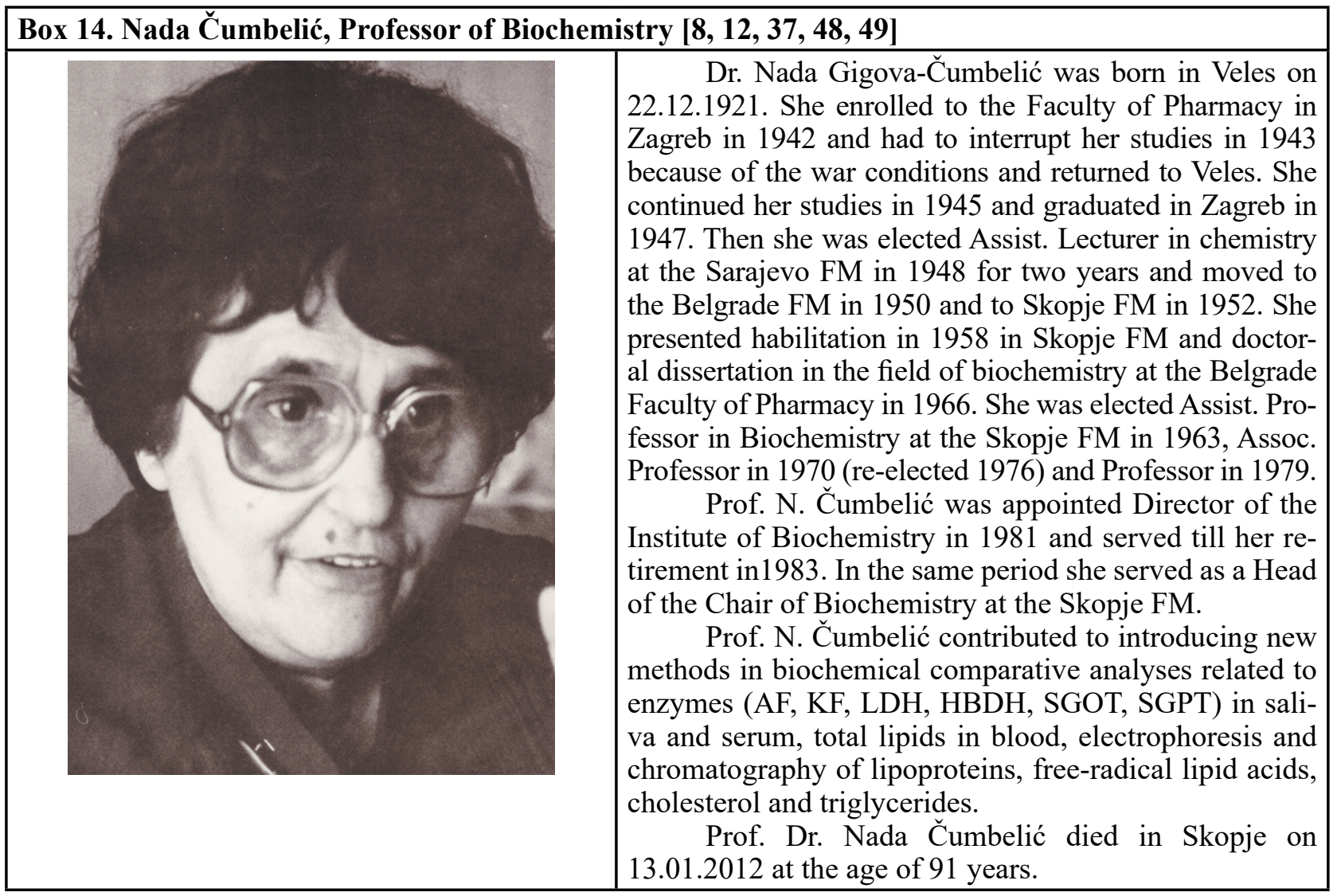

11. Development of the Institute and Chair of Pathological Anatomy

The Institute of Pathological Anatomy was founded in 1947, along with founding of the Skopje FM $[12,14]$. Initially, the Institute of Pathology performed its activities at the Institute of Hygiene and in the hospital chapel, and then moved into its own premises in the building of the institutes within the Faculty, which was built in 1948. The first Head of the Institute of Pathology was Associate Professor Mirko Knežević from Zagreb, who served in Skopje for only few months and returned to the Zagreb FM at the end of 1947 $[11,12]$. In early 1948, Assist. Prof. Ruža Verner was appointed Acting Director of the Institute of Pathology. Then, in 1949, Assist. Prof. Dragoslav Miletic came from the Belgrade FM and devoted the rest of his professional potential and career to the development of the Institute of Pathological Anatomy at the Skopje FM, till his retirement in 1978 [5, 12]. In 1960 Dr. Epsa Urumova and in 1963 Dr. Ljupčo Grozdev (Box 15) were elected as Assistant Professors at the Skopje FM.

The Institute of Pathological Anatomy played a significant role in delivering all types of education at undergraduate and postgraduate teaching and specialization levels. At the same time the Institute developed important diagnos- tic work, such as biopsy, autopsy and other types of analysis as an integral part of general medical practice in Macedonia and beyond. Special attention was devoted to research work as a factor in advancing the delivery of professional and teaching activities and health services.

\section{Development of the Institute and Chair of Pathophysiology and Nuclear Medicine}

The Institute of Pathological Physiology, from 1947-52, was integrated within the Institute of Physiology, founded by Prof. Miloe Vidaković [5, $8,12]$. The separate Chair of Pathological Physiology was created in the same premises in 1949 and the first Acting Head of the Chair was Prof. Miloe Vidaković, 1949-52 [5, 12, 15]. In this period the Institute of Pathological Physiology was situated within the premises of the Building of the Institutes. Assistant Professor Ishac Tadžer was appointed as the first Director of the newly established independent Institute of Pathological Physiology, and Head of the Chair of Pathological Physiology in 1952 [6]. A year later, in 1953, a final year student of medicine, later on Professor, Borislav Karanfilski (Box 16) joined the Institute of Pathophysiology as practical exercises demonstrator and, after graduation, was elected Assist. Lecturer in 1956. In 1956, the Institute of Pathological Physiology moved to 
the Clinical block building, with premises on the ground floor, while in 1964 the Institute was placed in a separate new building with about $1200 \mathrm{~m}^{2}$ functional area. In 1958, a laboratory for the use of radioisotopes in clinical trials and outpatient services started to be active in the Institute with the new name of the Institute of Pathophysiology and Nuclear Medicine [11, 12].

\begin{tabular}{|l|l|}
\hline Box 15. Ljupčo Grozdev, Professor of Pathological Anatomy [12, 17, 33, 44] \\
\hline & $\begin{array}{l}\text { Dr. Ljupč Grozdev was born in Štip on } \\
\text { 27.05.1930. He started medical studies in Skopje in } \\
1948 \text { and graduated in 1955. He joined the Institute of } \\
\text { Pathology at the Skopje FM and started specialization in } \\
\text { pathological anatomy. He completed his specialization in } \\
\text { 1960. During the specialization he visited centers of pa- } \\
\text { thology in Belgrade, Zagreb and Ljubljana and, in 1963- } \\
\text { 64, he spent two years at the Harvard Institute of Cancer } \\
\text { in Boston, USA, devoted to the research in the field of } \\
\text { oncology, especially biopsy and molecular pathology of } \\
\text { malignancies. Later on, he introduced a number of new } \\
\text { methods and founded the Laboratory for electronic mi- } \\
\text { croscopy within the Institute of Pathology. } \\
\text { Dr. Lj. Grozdev was elected Assist. Lecturer in } \\
\text { Pathology at the Skopje FM in 1958, and then Assist. } \\
\text { Professor in1963, Assoc. Professor in 1968 (re-elected in } \\
\text { 1978) and Professor in 1980. } \\
\text { Prof. Lj. Grozdev served many health-professional } \\
\text { and social policy functions in Macedonia and Yugoslavia. } \\
\text { Prof. Dr. Ljupč Grozdev died in Skopje on } \\
\text { 24.12.1989 at the age of 59 years. }\end{array}$ \\
\hline
\end{tabular}

Box 16. Borislav Karanfilski, Professor of Pathological Physiology $[12,17,18,34,44,50]$

\begin{tabular}{|l|l|}
\hline $\begin{array}{l}\text { Dr. Borislav Karanfilski was born in Kumanovo on } \\
\text { 31.08.1928. He graduated at the Skopje FM in } 1955 \text { and } \\
\text { was elected Assist. Lecturer in 1956. Then he started spe- } \\
\text { cialization in pathological physiology in Belgrade (Vinča) } \\
\text { in } 1957 \text { and supplemented it with specialization in funda- } \\
\text { mental and experimental application of radioactive iso- } \\
\text { topes in medical research in 1960 in London and Moscow, } \\
\text { and in immunity disorders and cancer of thyroid gland in } \\
\text { 1970s in Stockholm, Boston, Edinburgh and Chicago. He } \\
\text { presented doctoral dissertation in 1962 and was elected } \\
\text { Assistant Professor in 1963, then Associate Professor in } \\
1968 \text { (re-elected in 1974), and Professor in Pathological } \\
\text { Physiology at the Skopje FM in 1977. } \\
\text { Prof. B. Karanfilski contributed to the establishment } \\
\text { of the Laboratory of Nuclear Medicine within the Institute } \\
\text { of Pathological Physiology. He was appointed Director of } \\
\text { the Institute and Head of the Chair of Pathophysiology and } \\
\text { Nuclear Medicine in the period from 1978-88. He served as } \\
\text { Vice-dean (1971-73) and Dean of the Skopje FM (1982-84), } \\
\text { as well as Vice-Rector of the University in Skopje, President } \\
\text { of the Macedonian Medical Society (1971-72), President of } \\
\text { the Association of Nuclear Medicine of Yugoslavia (1979- } \\
82), \text { and starting from 1997 - President of the Committee } \\
\text { for Iodine Deficiency in R. Macedonia and Country Coor- } \\
\text { dinator of the International Council of Iodine Deficiency } \\
\text { Disorders. } \\
\text { Prof. Dr. Borislav Karanfilski now lives in Skopje at }\end{array}$ \\
his age of 90 years.
\end{tabular}




\section{Development of the Institute and Chair of Histology and Embryology}

The first temporary premises of the Institute of Histology and Embryology were provided in 1947 within the Deker's shed in the grounds of the former Institute of Hygiene. In 1948 the Institute was moved into the Institutes building, first in facil- ities shared with the Institute of Anatomy, and then in its own premises $[8,11,12]$. The first teacher of histology and embryology, Assistant Professor Dr. Ruža Verner, was appointed in 1947 [4]. She was appointed Director of the Institute of Histology and Embryology in 1948. In 1963 as a second lecturer in this institute was elected Asist. Prof. Marika Petruševska (Box 17).

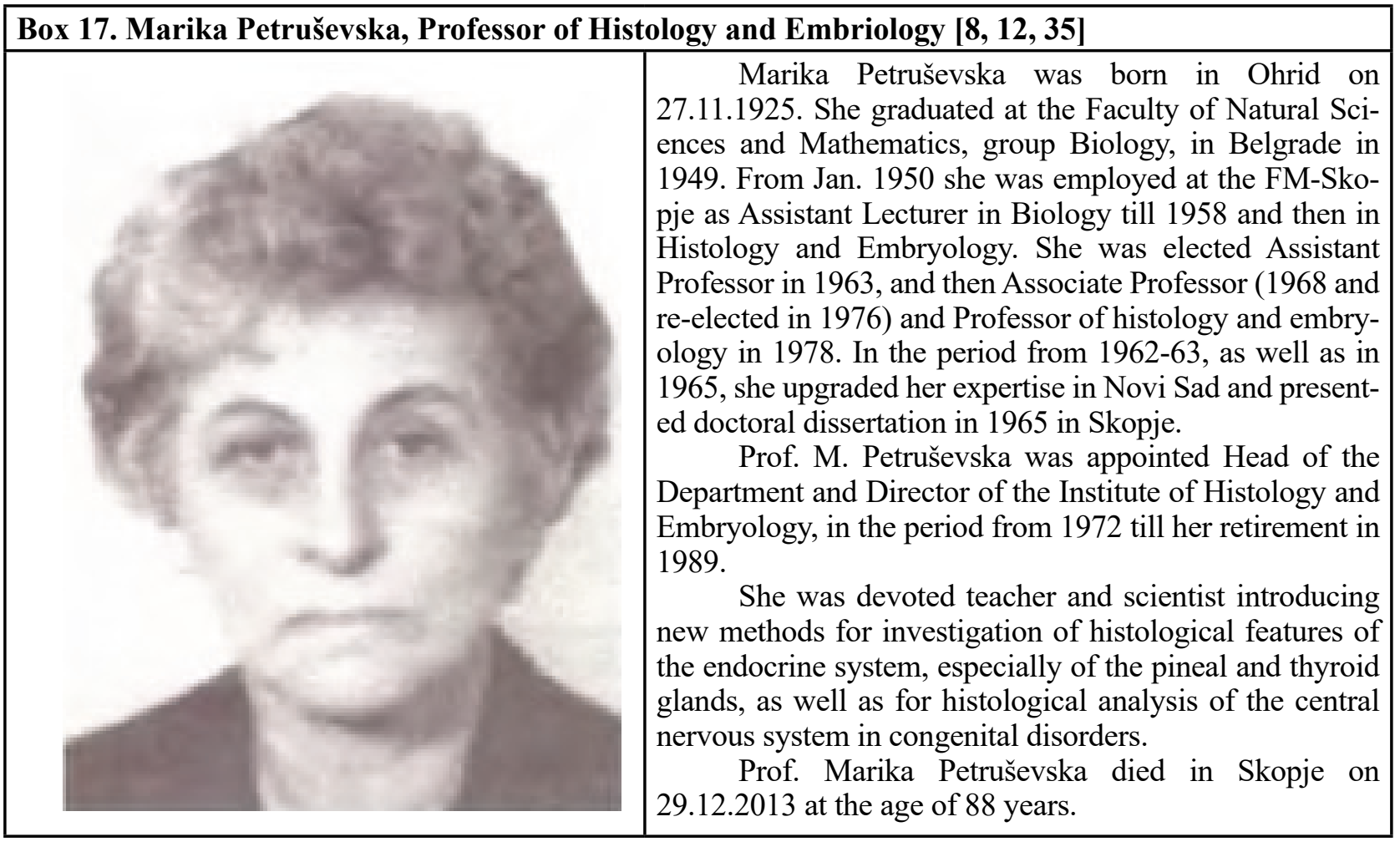

Besides the above-mentioned 17 teachers from Macedonia of the third group (elected assistant professors from 1961-63), 24 teachers from Macedonia of the second group (elected from 1955-60), [7], and the founders of the Skopje FM, 15 teachers from Macedonia [6], 12 from Serbia [5] and 11 from Croatia [4], who made a key contribution to the establishment and/or initial development of certain departments, institutes and clinics of the Skopje FM in the period 1947-63 and beyond, many other professional practitioners and auxiliary teaching staff from Macedonia and other republics in Yugoslavia participated in the work of the various institutes and clinics and in the realization of, first of all, practical teaching activities.

\section{DISCUSSION}

The third group of 17 young Macedonian lecturers, elected assistant professors for the first time at the Skopje FM in early 1960s, just in three-year period from 1961-63, made a remarkable contribution to the further development of certain departments/chairs and organizational units (clinics and institutes) and to the overall healthcare professional, research and educational activities at the Skopje FM in 1960s and later. Most of them completed their medical studies at the Belgrade FM (10 or $58.8 \%$ ), then at the $\mathrm{Za}$ greb FM (3 or $17.6 \%$ ), Skopje FM (3 or $17.6 \%$ ), and just one of them at the Graz FM (Table 1).

Later on, in the 1960s and 1970s, the Skopje FM was the main source and self-supplier of graduates which recruited them as its own academic and scientific staff.

Of the first generation of students who enrolled at the Skopje FM in 1947 and graduated from it in 1953 and later, some 20 doctors received teaching titles at the same Faculty during the 1960s $[7,12,51]$. Thus, the most reliable route for progress in the future and for further development of the 
health system was provided, while teaching and educational activities and research with new achievements and lasting results confirmed the reputation of the Skopje FM, of which Macedonia is proud.

Skopje FM played a crucial role in the education of medical professionals, in improving the poor health status of the population and the overall further development of the health system and provision of health care to the population of Macedonia. Medical science in R. Macedonia today fits completely into modern European and world trends. The Skopje FM has experienced a huge staff increase and today has highly-specialized personnel and modern equipment. A total number of 19 teachers and three assist. lecturers began the educational activities in 1947, while 70 years later, in 2016/17 academic year, the number of teachers was 223 (118 professors, 45 associate professors and 60 assistant professors), [52]. That is the impressive intellectual, educational and scientific potential of the Faculty. Today the Skopje FM is consisted of 36 depart- ments/chairs, 12 institutes, 3 centers, laboratories, library, administrative services and logistics, as well as 11 educational associated institutions and 29 university clinics contributing to the teaching process through the relevant departments/chairs. In addition to the teaching staff mentioned above, there are 6 scientific advisers, 9 higher scientific collaborators, 6 titular assoc. professors, 16 titular assist. professors, 70 assist. lecturers, 24 younger assist lecturers, 156 assist. lecturers $\mathrm{PhD}$ candidates, and 1 assist. researcher [52].

Up to the end of 2016, about 18,000 medical students had been enrolled at the Skopje FM, of whom 11,486 had graduated. Over the past 70 years Skopje FM has been the main source of doctors for continuous transfusion to the health system, for the development of health services and provision of the highest medical service in R. Macedonia, as well as for the development of scientific research work, $[1-5,10,12,52-54]$. From the early 1960 s the number of medical doctors employed in R. Mace-

Table 2. Physicians and other health workers employed in health organizations in the public sector in R. Macedonia in the period 1961-2016

\begin{tabular}{|c|c|c|c|c|c|c|c|c|c|c|}
\hline \multicolumn{4}{|c|}{ Profiles of health workers } & 1961 & 1971 & 1981 & 1991 & 2001 & 2011 & 2016 \\
\hline \multicolumn{4}{|c|}{ Total number of doctors } & 681 & 1519 & 2809 & 4487 & 4459 & 3509 & 3965 \\
\hline \multirow{3}{*}{ 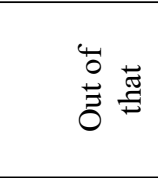 } & \multicolumn{3}{|l|}{ Specialists } & 265 & 689 & 1422 & 2296 & 2894 & 2607 & 2673 \\
\hline & \multicolumn{3}{|c|}{ On specialization } & 33 & 126 & 319 & 610 & 516 & 296 & 558 \\
\hline & \multicolumn{3}{|c|}{ General practitioners } & 383 & 550 & 1016 & 1581 & 1049 & 606 & 704 \\
\hline \multirow{2}{*}{\multicolumn{2}{|c|}{$\begin{array}{l}\text { Doctors in hospital health } \\
\text { care }\end{array}$}} & \multicolumn{2}{|c|}{ Number } & 394 & 495 & 793 & 1337 & 1555 & 1790 & 2006 \\
\hline & & \multicolumn{2}{|c|}{$\begin{array}{c}\% \text { from total } \\
\text { number of } \\
\text { doctors }\end{array}$} & 57.9 & 32.6 & 28.2 & 29.8 & 34.9 & 51.0 & 50.6 \\
\hline \multicolumn{4}{|c|}{$\begin{array}{l}\text { Nurses and other health workers with high level } \\
\text { education }\end{array}$} & 9 & 366 & 597 & 566 & 726 & & \\
\hline \multicolumn{4}{|c|}{$\begin{array}{l}\text { Nurses and other health workers with mid level } \\
\text { education }\end{array}$} & 1569 & 3462 & 6479 & 9614 & 9827 & 8137 & 8084 \\
\hline \multicolumn{4}{|c|}{$\begin{array}{l}\text { Auxiliary health workers (low level of } \\
\text { education) }\end{array}$} & 680 & 1331 & 1159 & 891 & 509 & 458 & 449 \\
\hline \multicolumn{4}{|c|}{ Health co-workers } & - & - & - & 231 & 421 & 920 & 1879 \\
\hline \multirow{2}{*}{\multicolumn{3}{|c|}{$\begin{array}{l}\text { Administrative workers and technical } \\
\text { personnel }\end{array}$}} & Number & 2139 & 3847 & 4991 & 5503 & 5830 & 4918 & 5240 \\
\hline & & & $\%$ & 38.9 & 35.9 & 29.8 & 24.1 & 25.1 & 26.7 & 26.1 \\
\hline \multicolumn{4}{|c|}{$\begin{array}{l}\text { Total number of employed in the health } \\
\text { institutions (public sector) }\end{array}$} & 5493 & 10714 & 16739 & 22817 & 23206 & 18409 & 20070 \\
\hline \multirow{3}{*}{ 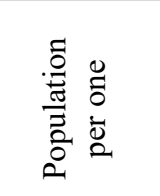 } & \multicolumn{3}{|c|}{ Doctor (total) } & 1973 & 1209 & 697 & 454 & 456 & 587 & 523 \\
\hline & \multicolumn{3}{|c|}{ General practitioner } & 3671 & 2995 & 1879 & 1290 & 1940 & 2282 & 1604 \\
\hline & \multicolumn{3}{|c|}{$\begin{array}{l}\text { Health workers with mid and } \\
\text { high level education }\end{array}$} & 891 & 430 & 270 & 200 & 193 & 253 & 256 \\
\hline \multicolumn{4}{|c|}{$\begin{array}{l}\text { Health workers with mid and high level of } \\
\text { education per } 1 \text { doctor }\end{array}$} & 2.3 & 2.5 & 2.6 & 2.3 & 2.4 & 2.3 & 2.0 \\
\hline
\end{tabular}

Source: Institute of Public Health, Skopje State Statistical Office of R. Macedonia 
Table 3. Health workers in the private health sector in R. Macedonia in the period 2001-2016

\begin{tabular}{|c|c|c|c|c|c|}
\hline \multicolumn{2}{|c|}{ Profiles of health workers } & 2001 & 2004 & 2011 & 2016 \\
\hline \multirow{3}{*}{ Doctors } & Total & 481 & 641 & 2140 & 2245 \\
\hline & General practitioners & 260 & 365 & 1183 & 1203 \\
\hline & Specialists & 221 & 276 & 957 & 1042 \\
\hline \multirow{3}{*}{ Stomatologists } & Total & 278 & 468 & 1254 & 1461 \\
\hline & General stomatology & 226 & 379 & 981 & 1174 \\
\hline & Specialists & 52 & 89 & 273 & 287 \\
\hline \multicolumn{2}{|l|}{ Pharmacists } & 259 & 430 & 683 & 911 \\
\hline \multicolumn{2}{|c|}{ Other with university level education } & 29 & 47 & 184 & 469 \\
\hline \multicolumn{2}{|c|}{ Total number of workers with university level education } & 1047 & 1586 & 4261 & 5086 \\
\hline \multicolumn{2}{|c|}{ Health workers with mid and high level eduvation } & 547 & 767 & 4508 & 5422 \\
\hline \multicolumn{2}{|l|}{ T O T A L } & 1621 & 2353 & 9053 & 11194 \\
\hline
\end{tabular}

Source: Institute of Public Health, Skopje

donia in the health services, in both the public and private sectors, was constantly increasing so that in 2016 the number of medical doctors reached 6,210 ( 3715 of these, or $59.8 \%$, specialist physicians). The supply ratio of medical doctors to population in $\mathrm{R}$. Macedonia, which in 2016 was estimated to about 2.05 million, was 1 medical doctor per 330 inhabitants (Tables 2 and 3 ).

The Skopje FM was and continues to be Alma Mater for other educational institutions in the field of biomedicine in R. Macedonia. The
Skopje FM was the basis for the formation of the Department of Dentistry, in 1959, and then the Faculty of Dentistry in Skopje in 1977. In the same year, 1977, the Faculty of Pharmacy in Skopje was established, too $[1-3,7,12$, 52]. The shortfalls in educated personnel were steadily reduced in the dental services from the 1960s and in the pharmaceutical services and pharmacies from the 1980s. The total number of stomatologists in the public and private sector in 2016 reached 1,806 with the supply ratio of 1

Table 4. Health workers in the Dental and Pharmaceutical services and pharmacies in the public health sector in R. Macedonia in the period 1961-2016

\begin{tabular}{|c|c|c|c|c|c|c|c|c|}
\hline \multicolumn{2}{|c|}{ Profiles of health workers } & 1961 & 1971 & 1981 & 1991 & 2001 & 2011 & 2016 \\
\hline \multicolumn{2}{|c|}{ Stomatologists, total number } & 47 & 251 & 553 & 1118 & 1125 & 368 & 345 \\
\hline \multirow[b]{2}{*}{ 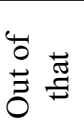 } & with specialization & 5* & 38 & 154 & 271 & 411 & 213 & 212 \\
\hline & without specialization & 42 & 214 & 373 & 777 & 689 & 155 & 133 \\
\hline \multicolumn{2}{|c|}{$\begin{array}{l}\text { Dentists with mid and high level } \\
\text { education }\end{array}$} & 182 & 250 & 218 & 121 & 40 & 0 & 0 \\
\hline \multicolumn{2}{|c|}{ Dental technicians } & 172 & 316 & 406 & 448 & 378 & 101 & 66 \\
\hline \multirow[b]{2}{*}{ 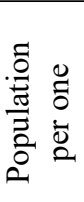 } & Stomatologist & 29915 & 6563 & 3452 & 1824 & 1809 & 5594 & 6007 \\
\hline & $\begin{array}{l}\text { Dentist with mid and high } \\
\text { level education }\end{array}$ & 10733 & 6589 & 8758 & 16850 & 50872 & - & - \\
\hline \multicolumn{2}{|c|}{$\begin{array}{l}\text { Dental technicians with mid and high } \\
\text { level education per } 1 \text { stomatologist }\end{array}$} & 5.2 & 1.3 & 0.8 & 0.4 & 0.3 & 0.27 & 0.19 \\
\hline \multicolumn{2}{|c|}{ Pharmacists, total number } & 120 & 163 & 155 & 393 & 309 & 99 & 108 \\
\hline \multirow[b]{2}{*}{ 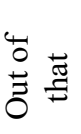 } & with specialization & 6 & 16 & 30 & 42 & 61 & 41 & 46 \\
\hline & without specialization & 114 & 147 & 125 & 351 & 248 & 58 & 62 \\
\hline \multicolumn{2}{|c|}{ Pharmaceutical technicians } & 189 & 441 & 495 & - & 407 & 84 & 102 \\
\hline \multicolumn{2}{|c|}{ Population per 1 pharmacist } & 11717 & 10106 & 12317 & 5188 & 6585 & 20793 & 19190 \\
\hline \multicolumn{2}{|c|}{$\begin{array}{l}\text { Pharmaceutical technicians per } 1 \\
\text { pharmacist }\end{array}$} & 1.6 & 2.7 & 3.3 & - & 1.7 & 0.85 & 0.94 \\
\hline
\end{tabular}

* on specialization

Source: Institute of Public Health, Skopje State Statistical Office of R. Macedonia 
stomatologist per 1,135 inhabitants, and the total number of pharmacists reached 1,019 with the supply ratio of 1 pharmacist per 2012 inhabitants (Table 3 and 4 ).

A number of health status indicators related to infectious diseases, morbidity and mortality in general, and quality of life, present remarkable improvements, and life expectancy at birth has increased from 47.05 (males 45.9; females 48.2 ) in 1948 to 75.5 years (males 73.5 ; females $77.4)$ in 2016 [55-57].

This paper, the fifth in the series in the field of history of medicine in Macedonia associated with the beginnings and the first doyens of the Skopje FM, printed in the MASA Journal Prilozi - Contributions, compliments the entirety of about 80 teachers in the period 1947-63, most of them doctors, participating in the establishment and initial development of Skopje FM. Our research, published in the five papers, should stimulate physicians in Macedonia to devote much more to research in the field of medical history in Macedonia.

There is still much to explore from each area of the history of medicine in R. Macedonia. We now restrict ourselves to the beginnings and initial development of the Skopje FM carried out by the first few groups of about 80 lecturers and, in this paper focused to the third group of 17 Macedonian doyens being elected lecturers for the first time in the period 1961-63.

\section{LIMITATIONS OF THE STUDY}

More detailed data about some of the lecturers from Macedonia are not available within the sources used for this study. The primary and most reliable sources were the reports from Bulletins of the University about the election of lecturers at the Skopje FM. Some data and photographs were collected from descendents and relatives or from a few still living professors. Nevertheless, the data we have collected from various alternative sources provide a clear picture of the important contribution of the third group of doctors and lecturers from Macedonia, elected as assistant professors from 1961 to 1963, to the further development of the Faculty of Medicine and the Department/Faculty of Dentistry and Faculty of Pharmacy in Skopje in the 1960s and later.

\section{CONCLUSION}

Establishing the Skopje FM in 1947 was an exceptional event of crucial importance for the development of educational, scientific and highly specialized health care in R. Macedonia. In the past seventy years the Skopje FM has made and continues to make a major contribution to the creation of highly specialized medical staff for the health care system, as well as to the provision of the best available health care for the population of the Republic of Macedonia and beyond. From its foundation until the present day the educational role of the Skopje FM has been essential in the education of more than 11,000 doctors in R. Macedonia.

Besides the first two groups of total 39 Macedonian lecturers and the teachers who came from other medical faculties in Yugoslavia, mainly from Belgrade - 12 and from Zagreb FM - 11, especially great appreciation goes to the third group of 17 teachers from Macedonia, elected in various fields of medicine from 1961-63, who invested their efforts, enthusiasm, creativity, expertise and professionalism in the further development of the Skopje FM. All of them marked the history of medicine in Macedonia and remain in the collective memory as giants of the medical education and lasting impetus and inspiration for the future generations in R. Macedonia and broader. Thus the Skopje FM and R. Macedonia are indebted to all those pioneers and corypheés of medicine for their contribution to the establishment and development of the Skopje FM and the development of medical science and health services in the country.

Our predecessors, with great enthusiasm, sacrifice and constant work managed to provide a strong impetus for the initial and further development of the Skopje FM and the medicine in R. Macedonia to a high level, recognized in Europe and broader. Their legacy for all subsequent generations is to continue the tireless work and high professional commitment for education of health professionals and to provide all citizens in $\mathrm{R}$. Macedonia with the best of medicine in terms of modern and quality health care services and methods in accordance with international standards.

\section{Acknowledgement}

The authors wish to express their sincere gratitude to the emeritus professors Kočo Serafimov and 
Borislav Karanfilski for sharing their views and experiences about some of the lecturers from $\mathrm{R}$. Macedonia who contributed to the establishment and for further development of certain clinics and institutes and of the Skopje FM in general. The authors would like to thank Ms. Lenče Danevska, Chief of the Central Medical Library at the Skopje FM, and her collaborator Ms. Biljana Ristoska, as well as to former and current chief Chief of the Library at the Macedonian Academy of Sciences and Arts, Ms. Nade Georgievska and Mr. Slavčo Taševski, for their support in providing relevant data and information from archive materials, university bulletins and other publications related to the doyens at the Skopje FM.

\section{REFERENCES}

1. Lazarevski M, Nikodijević B, Velkov $\mathrm{K}$, Čaparoski R, Glavaš E. Establishment and 40year development of the Faculty of Medicine in Skopje (1947-1987). [In Macedonian]. In: Lazarevski M., Editor-in-Chief. Faculty of Medicine in Skopje 1947-1987. Faculty of Medicine, Ss Cyril and Methodius University, Skopje. Skopje, 1987: 15-50.

2. Nikodijević B. Establishment of the Faculty of Medicine in Skopje in 1947. [In Macedonian]. In: Nikodijević B., Antova N., Šumkovski M., eds. Almanac of the First Generation of Students at the Faculty of Medicine in Skopje 1947-1953. Faculty of Medicine, Ss Cyril and Methodius University, Skopje. Skopje, 1997: 11-19.

3. Polenaković M. Forty Years since the Establishment of the Association of Societies of Doctors in Macedonia. [In Macedonian]. Macedonian Medical Review 1985; 39(3-4): 77-86.

4. Polenakovic M, Donev D. Contributions of the doctors from Croatia in establishing and initial development of the Faculty of Medicine in Skopje, Republic of Macedonia. Prilozi-Contributions, Sec. Biol. Med. Sci., MASA 2011; 32(2): 331-58 Available from: http://manu.edu.mk/ prilozi/26p.pdf

5. Donev D, Polenaković M. Contributions of the doctors from Serbia to the establishment and initial development of the Faculty of Medicine in Skopje, Republic of Macedonia. Prilozi-Contributions, Sec. Biol. Med. Sci., MASA 2012; 33(1): 319-46. Available from: http://www.manu.edu. $\mathrm{mk} /$ prilozi/jully2012/CONTRIBUTIONS $\% 20$ OF\%20DOCTORS\%20FROM\%20SERBIA.pdf
6. Donev D, Polenakovic M. Contributions of the doctors from Macedonia to the establishment and initial development of the Faculty of Medicine in Skopje, Republic of Macedonia. Prilozi-Contributions, Sec. Biol. Med. Sci., MASA 2012; 33(2): 239-77. Available from: http://www.manu. edu.mk/prilozi/2012_2/20d.pdf

7. Donev D, Polenakovic M. Doctors and lecturers from Macedonia elected for the first time at the Faculty of Medicine in Skopje in the period 1955-1960. Prilozi-Contributions, Sec. Biol. Med. Sci., MASA 2013; 34 (3): 121-44. Available at: http://manu.edu.mk/prilozi/01dd.pdf

8. Žanteva-Naumoska M, Dimitrijevski M, Georgievska-Ismail LJ, et al. Faculty of Medicine in Skopje 1947-2007 (Documents). [In Macedonian]. Faculty of Medicine, Ss Cyril and Methodius University, Skopje. Skopje, 1997: 201.

9. Maleska-Ivanovska V, Žanteva-Naumoska M, eds. 60 Years Faculty of Medicine, Ss Cyril and Methodius University in Skopje: 1947-2007. [In Macedonian]. Faculty of Medicine, Ss Cyril and Methodius University, Skopje. Skopje, 1997: 192.

10. Bogoev M. Welcoming Speech at the Golden Jubilee of the Medical Faculty in Skopje ceremony, March 17,1997. [In Macedonian]. In: Markovski A., ed. 50 Years of the Faculty of Medicine in Skopje. Faculty of Medicine, Ss Cyril and Methodius University, in Skopje. Skopje, 1998: 9-13.

11. Antevski D. Spatial conditions at the Faculty of Medicine in Skopje in the period from 19471953. [In Macedonian]. In: Nikodijevic B., Antova N., Šumkovski M., eds. Almanac of the First Generation of Students at the Faculty of Medicine in Skopje 1947-1953. Faculty of Medicine, Ss Cyril and Methodius University, Skopje. Skopje, 1997: 20-4.

12. Lazarevski M, Nikodijević B, Velkov K, Čaparoski R, Glavaš E. Development of the institutions within the Faculty of Medicine in Skopje. [In Macedonian]. In: Lazarevski M., Editor-in-Chief. Faculty of Medicine in Skopje 1947-1987. Faculty of Medicine, Ss Cyril and Methodius University, Skopje. Skopje, 1987: 183-345.

13. Trajkov D, Petličkovski A, Strezova A, Spiroski M. Sixty Years of the Faculty of Medicine in the Republic of Macedonia (1947-2007). Maced J Med Sci 2008; 1(1): 3-12. doi:10.3889/MJMS.18575773.2008.0011. Available from: http://www. mjms.ukim.edu.mk/Online/MJMS_2008_1_1/ MJMS.1857-5773.2008.0011.pdf

14. Markovski A, ed. 50 Years of the Faculty of Medicine in Skopje. [In Macedonian]. Faculty of Medicine, Ss Cyril and Methodius University, Skopje. Skopje, 1998: 144. 
15. Karanfilski B. Our first teachers. [In Macedonian]. In: Nikodijević B., Antova N., Šumkovski M., eds. Almanac of the First Generation of Students at the Faculty of Medicine in Skopje 19471953. Faculty of Medicine, Ss Cyril and Methodius University, Skopje. Skopje, 1997: 16-19.

16. Stojčevski T, Nikodijević B. The first lecturers at the Faculty of Medicine in Skopje. [In Macedonian]. In: Nikodijević B., Antova N., Šumkovski M., eds. Almanac of the First Generation of Students at the Faculty of Medicine in Skopje 19471953. Faculty of Medicine, Ss Cyril and Methodius University, Skopje. Skopje, 1997: 53-67.

17. Ristovski B, Editor-in-Chief. Macedonian Encyclopedia, Part I. [In Macedonian]. Macedonian Academy of Sciences and Arts, Skopje. Skopje, 2009: 812 .

18. Tofoski J, ed. 60 Years Macedonian Medical Association 1945-2005. [In Macedonian]. Macedonian Medical Association, Skopje, 2008: 378.

19. Ristovski B, Editor-in-Chief. Macedonian Encyclopedia, Part II. [In Macedonian]. Macedonian Academy of Sciences and Arts, Skopje. Skopje, 2009: 813-1671.

20. Nakova M, editor. Fifty Years the Faculty of Dentistry in Skopje, 1959-2009. [In Macedonian]. Faculty of Dentistry Ss Cyril and Methodius University in Skopje, 2009: 232.

21. Tofović P, Serafimov K, Sadikario A, Andreevski A, Lazarov A, Refereees. Report on election of professor in orthopaedics (Dimko Kepeski) at the Faculty of Medicine in Skopje. [In Macedonian]. Bulletin of the University in Skopje No. 285, Dec 1977: 48-67.

22. Tadžer I, Perčinkovski R, Nedelkovski J, Referees. Report on election of professor in physiology (Vančo Kovačev) at the Faculty of Medicine in Skopje. [In Macedonian]. Bulletin of the University in Skopje No. 203, Nov 1973: 8-23.

23. Dragojevic B, Tevcev D, Referees. Report on election of assistant professor in radiology (Salvator Levi) at the Faculty of Medicine in Skopje. [In Macedonian]. Bulletin of the University in Skopje No. 36, Feb 1961: 23-9.

24. Tadžer I, Davčev P, Fildiševski P, Perčinkovski R, Kovačev V, Referees. Report on election of professor in pharmacology (Branislav Nikodijević) at the Faculty of Medicine in Skopje. [In Macedonian]. Bulletin of the University in Skopje No. 267, Apr 1977: 206-20.

25. Perišić S, Perčinkovski R, Sadikario A, Fildiševski P, Hadži-Boškov A, Referees. Report on election of professor in dermatovenerology (Remon Ruben) at the Faculty of Medicine in Skopje. [In Macedonian]. Bulletin of the University in Skopje No. 262, Feb. 1977: 52-65.
26. Magjanović N, Njemirovski Z, Smilev D, Andreevski A, Karakašević B, Referees. Report on election of professor in dental pathology and therapy (Ivan Tavčiovski) at the Faculty of Medicine in Skopje. [In Macedonian]. Bulletin of the University in Skopje No. 265, March 1977: 13244.

27. Dragojević B, Čakmakov A, Referees. Report on election of assistant professor in surgery (Mitruš Anastasov) at the Faculty of Medicine in Skopje. [In Macedonian]. Bulletin of the University in Skopje No. 48, Feb. 1962: 71-9.

28. Davčev P, Perčinkovski R, Hrisoho D, Nedelkovski J, Teodosievski D, Referees. Report on election of professor in internal medicine (Ljubomir Kotevski) at the Faculty of Medicine in Skopje. [In Macedonian]. Bulletin of the University in Skopje No. 262, Feb. 1977: 124-51.

29. Davčev P, Teodosievski D, Nedelkovski J, Tevčev D, Hadži-Boškov A, Referees. Report on election of professor in physiology (Kiril Minčev) at the Faculty of Medicine in Skopje. [In Macedonian]. Bulletin of the University in Skopje No. 265, March 1977: 20-8.

30. Panovski J, Miovski D, Davčev P, Andreevski A, Fildiševski P, Referees. Report on election of professor in surgery (Kočo Serafimov) at the Faculty of Medicine in Skopje. [In Macedonian]. Bulletin of the University in Skopje No. 262, Feb. 1977: 106-23.

31. Panovski J, Miovski D, Davčev P, Andreevski A, Fildiševski P, Referees. Report on election of professor in surgery (Petar Tofović) at the Faculty of Medicine in Skopje. [In Macedonian]. Bulletin of the University in Skopje No. 262, Feb. 1977: 152-72.

32. Urumova E, Tadžer I, Šukarov Lj, Karanfilski B, Mironski S, Referees. Report on election of professor in biochemistry (Aleksandra Babamova-Vilarova) at the Faculty of Medicine in Skopje. [In Macedonian]. Bulletin of the University in Skopje No. 310, Jan 1979: 10-15.

33. Urumova E, Tadžer I, Šukarov L. Karanfilski B, Mironski S, Referees. Report on election of professor in pathological anatomy (Ljupčo Grozdev) at the Faculty of Medicine in Skopje. [In Macedonian]. Bulletin of the University in Skopje No. 283, Nov. 1977: 1-10.

34. Tadžer I, Davčev P, Fildiševski P, Kovačev V, Urumova E, Referees. Report on election of professor in pathological physiology (Borislav Karanfilski) at the Faculty of Medicine in Skopje. [In Macedonian]. Bulletin of the University in Skopje No. 265, March 1977: 1-19.

35. Urumova E, Tadžer I, Andreevski A, Teodosievski D, Kovačev V, Referees. Report on election of 
professor in histology and embriology (Marika Petruševska) at the Faculty of Medicine in Skopje. [In Macedonian]. Bulletin of the University in Skopje No. 283, Nov 1977: 103-9.

36. Cvetković M, Nikodijević B, Kovačev V, Karanfilski B, Davčev P, Referees. Report on election of professor in biochemistry (Divna Taškova-Konstantinova) at the Faculty of Medicine in Skopje. [In Macedonian]. Bulletin of the University in Skopje No. 310, Jan 1979: 16-24.

37. Cvetković M, Nikodijević B, Kovačev V, Karanfilski B, Davčev P, Referees. Report on election of professor in biochemistry (Nada Čumbelić-Gigova) at the Faculty of Medicine in Skopje. [In Macedonian]. Bulletin of the University in Skopje No. No. 310, Jan 1979: 1-9.

38. Poposka A. Department of Orthopaedics. In: Topuzovska S, Popova-Jovanovska R, Danevska L, et al. Editors. 70 Years Faculty of Medicine. FM-Skopje, Skopje, 2017: 105-8.

39. Serafimov Lj. Retirement of Prof. Dr. Dimko Kepeski. [In Macedonian]. God zb Med fac Skopje $1983 ; 29(1)$ : 120-1.

40. Vox Medici. Doyens: Prof. Dr. Vancho Kovachev - the youngest docent at the FM-Skopje. [In Macedonian]. Vox Medici 2002; 10(36): 22-5.

41. Vox Medici. Doyens: Prof. Dr. Branislav Nikodijevic - the first specialist in clinical pharmacology. [In Macedonian].Vox Medici 2001; 9(30): 32-5.

42. Vox Medici. Prestige reward to Prof. Dr. Branislav Nikodijevic. [In Macedonian]. Vox Medici 2006; 14(52): 22-5.

43. Jankulovski N, Dimitrijevski M, Alabakovska S, et al. Eds. Deans at the Faculty of Medicine in Skopje 1947-2012. [In Macedonian]. Faculty of Medicine in Skopje, 2015: 173.

44. Stojkovski G. Macedonian artificers in medicine. [In Macedonian]. Publisher „Kultura“ - Skopje, 2001: 354.

45. Serafimov K. Surgery of the gallbladder and extrahepatic bile ducts. Publisher „Kultura“ - Skopje, 2003: 294.

46. Gligorovski Lj, Ed. Thirty years from the establishment of the clinics associated to the Chair of Internal Medicine, 1975-2005. [In Macedonian]. University Ss Cyril and Methodius Faculty of Medicine - Chair of Internal Medicine, Skopje, 2005: 109.
47. Džočkov J. Prof. Dr. Kiril Minčev - We started with only one X-Ray and great enthusiasm. [In Macedonian]. Vox Medici, 2009; 18(65): 28-30.

48. Stavrić Hrisoho R. Development of Biochemistry in Macedonia. Association of medical biochemists of Macedonia, Skopje, 1999: 596.

49. Džekova S. Retirement of Prof. Dr. Nada Čumbelić. [In Macedonian]. God zb Med fac Skopje 1983; 29(1): 116-7.

50. Džočkov J. Prof. Dr. Borislav Karanfilski - The third doctor of science at the Faculty of Medicine in Skopje. [In Macedonian]. Vox Medici, March 2009; 18(62): 26-9.

51. Šumkovski M. Demonstrators from the first generation. [In Macedonian]. In: Nikodijević B., Antova N., Sumkovski M., eds. Almanac of the First Generation of Students at the Faculty of Medicine in Skopje 1947-1953. Faculty of Medicine, Ss Cyril and Methodius University, Skopje. Skopje, 1997: 29-30.

52. Topuzovska S, Popova-Jovanovska R, Danevska L, editors. 70 years Faculty of Medicine in Skopje, 1947-2017. FM-Skopje, Skopje, 2017: 208.

53. Žanteva-Naumoska M, Polenaković M. Sixty years since the foundation of the Medical Faculty at the Ss Cyril and Methodius University in Skopje, R. Macedonia (1947-2007). Prilozi/Contributions, Sec. Biol. Med. Sci., MASA, 2008; 29(1): 303-7.

54. Donev D. Revitalization of Academic Medicine in Macedonia - An Urgent Need. Croat Med J 2004; 45(6): 677-83. PMID:15578799 [PubMed - indexed for MEDLINE]. Available from: http:// www.cmj.hr/2004/45/6/15578799.htm Accessed: Oct 6, 2012.

55. Federal Institute for Statistics of the Socialist Federative Republic of Yugoslavia. Statistical Yearbook of Yugoslavia 1979. Federal Institute of Statistics of the SFR Yugoslavia, Belgrade, 1979.

56. State Statistical Office of the Republic of Macedonia. Statistical Yearbook of Macedonia 2017. State Statistical Office of the Republic of Macedonia, Skopje, 2017

57. Country Economy. Republic of Macedonia Life expectancy at birth. Available at: https:// countryeconomy.com/demography/life-expectancy/macedonia 
Резиме

\title{
ДОКТОРИ-НАСТАВНИЦИ ОД МАКЕДОНИЈА ШТО СЕ ИЗБРАНИ ЗА ПРВПАТ НА МЕДИЦИНСКИОТ ФАКУЛТЕТ ВО СКОПЈЕ ВО ПЕРИОДОТ 1961-1963 ГОДИНА
}

\author{
Дончо Донев ${ }^{1}$, Момир Поленаковиќ́ 2 Нада Поп-Јорданова² \\ ${ }^{1}$ Институт за социјална медицина, Медицински факултет, Универзитет „Св. Кирил и Методиј“ во Скопје, \\ Република Македонија \\ ${ }^{2}$ Македонска академија на науките и уметностите, Скопје, Република Македонија
}

Цел: Да се прикаже група млади доктори од Р. Македонија, кои биле избрани во наставници на Медицинскиот факултет (МФ) во Скопје, Р. Македонија, во периодот од 1961 до 1963 г.

Методи: Ретроспективна студија базирана на архивски материјали, енциклопедии и јубилејни публикации на Медицинскиот и на Стоматолошкиот факултет во Скопје, други релевантни извори на информации и преглед на релевантна литература.

Резултати: МФ - Скопје е основан во 1947 г., а првиот состанок на Советот на наставниците бил одржан на 17.3.1947 г. Првата генерација од 153 студенти се запишала во есента 1947 г., а првото предавање е одржано на 3.11.1947 г.

Покрај 15 доктори од Р. Македонија - наставен кадар, кој бил именуван во периодот од 1947 до 1954 г., и група од 24 наставници од Р. Македонија избрани во доценти во периодот од 1955 до 1960 г., една дополнителна група од 17 македонски наставници биле избрани за првпат во периодот од 1961 до 1963 г. Тие 56 пионери и корифеи на медицината во Р. Македонија играле важни улоги во основањето и/или во иницијалниот и натамошниот развој на голем број катедри, институти и клиники на новоформираниот МФ - Скопје во 1947 г. и во првите 15-20 години од неговиот иницијален развој, до 1960-тите години и потоа.

Заклучок: МФ - Скопје, основан во 1947 г., одигра суштествена улога за едукација на медицински стручњаци, за подобрување на крајно влошената здравствена состојба на населението и за севкупниот натамошен развој на здравствениот систем и обезбедувањето на здравствената заштита на населението во Р. Македонија. Придонесот на третата група од 17 наставници од Р. Македонија за натамошниот развој на МФ - Скопје, во периодот од 1960-тите и потоа, беше од големо значење.

Клучни зборови: факултет, медицински; основање, иницијален развој; едукација, медицинска; настава; Република Македонија; доктори од Р. Македонија 